\title{
EVALUATION OF A BUNDLE TO PREVENT VENTILATOR-ASSOCIATED PNEUMONIA IN AN INTENSIVE CARE UNIT ${ }^{1}$
}

\author{
Sabrina Guterres da Silva², Raquel Kuerten de Salles ${ }^{3}$, Eliane Regina Pereira do Nascimento ${ }^{4}$, Kátia Cilene \\ Godinho Bertoncello ${ }^{5}$, Cibele D'Avila Kramer Cavalcanti ${ }^{6}$
}

\footnotetext{
${ }^{1}$ This article is part of the master's thesis - Conformity assessment of care that integrate a bundle to prevent ventilator-associated pneumonia in Intesive Care Unit, presented to the Multiprofessional Master of Health Sciences, at the Universidade Federal de Santa Catarina (UFSC), in 2013.

${ }^{2}$ Doctoral student, Nursing Graduate Program, UFSC. Florianópolis, Santa Catarina, Brazil. E-mail: sabrinaguterres@gmail.com

${ }^{3}$ Ph.D. in Production Engineering. Associate Professor, Department of Nutrition, UFSC. Florianópolis, Santa Catarina, Brazil. E-mail: raquel@hu.ufsc.br

${ }^{4}$ Ph.D. in Nursing. Associate Professor, Nursing Department, UFSC. Florianópolis, Santa Catarina, Brazil. E-mail: pongopam@ terra.com.br

${ }^{5}$ Ph.D. in Nursing. Adjunct Professor, Nursing Department, UFSC. Florianópolis, Santa Catarina, Brazil. E-mail: kbertoncello@ yahoo.com.br

${ }^{6}$ Nurse at the Florianópolis Hospital. Florianópolis, Santa Catarina, Brazil. E-mail: cibelekramer@gmail.com
}

\begin{abstract}
We aimed at evaluating compliance with a bundle to prevent ventilator-associated pneumonia in an Intensive Care Unit. It is a quantitative, descriptive and cross-sectional study, conducted in a public hospital in the state of Santa Catarina. Data were collected in July and August of 2012. The sample consisted of 1,146 observations of the four elements that compose the bundle (head of bed elevation between $30-45^{\circ}$; endotracheal suctioning; cuff pressure between $20-30 \mathrm{cmH}_{2} \mathrm{O}$; and oral care with $0.12 \%$ chlorhexidine). Expected compliance was equal to a positivity rate $\geq 80 \%$. Data analysis revealed overall bundle compliance of $794(69.2 \%)$. When analyzed separately, two practices presented expected compliance $(84.7 \%)$ : oral care and suctioning. Head of bed elevation had the lowest compliance $(55.5 \%)$, followed by cuff pressure (61.8\%). We observed the need for strategies that promote the quality of all the elements that compose the bundle in order for its use to be effective.
\end{abstract}

DESCRIPTORS: Intensive care units. Pneumonia, ventilator-associated. Nursing assessment. Patient care team.

\section{AVALIAÇÃO DE UM BUNDLE DE PREVENÇÃO DA PNEUMONIA ASSOCIADA À VENTILAÇÃO MECÂNICA EM UNIDADE DE TERAPIA INTENSIVA}

RESUMO: Objetivou-se avaliar a conformidade de um bundle de prevenção da pneumonia associada à ventilação mecânica em Unidade de Terapia Intensiva. Trata-se de estudo descritivo, transversal e quantitativo, realizado em um hospital público de Santa Catarina. Os dados foram coletados em julho e agosto de 2012. A amostra correspondeu a 1.147 observações das quatro práticas que compõem o bundle (cabeceira elevada $30-45^{\circ}$; aspiração endotraqueal; pressão do cuff entre $20-30 \mathrm{cmH}_{2} \mathrm{O}$; e higiene oral com clorexidina 0,12\%). Adotou-se como conformidade esperada um Índice de Positividade $\geq 80 \%$. A análise dos dados revelou uma conformidade geral do bundle de 794 (69,2\%). Avaliadas isoladamente, duas práticas apresentaram conformidade esperada (84,7\%): a higiene oral e a aspiração. A cabeceira elevada foi a que obteve menor conformidade (55,5\%), seguida pela pressão do cuff (61,8\%). Observa-se a necessidade de estratégias que promovam a qualidade de todos os cuidados que compõem o bundle para alcançar efetividade em sua utilização. DESCRITORES: Unidades de Terapia Intensiva. Pneumonia associada à ventilação mecânica. Avaliação em enfermagem. Equipe de assistência ao paciente. 


\title{
EVALUACIÓN DE UN PAQUETE DE PREVENCIÓN DE LA NEUMONÍA ASOCIADA A VENTILACIÓN MECÁNICA EN LA UNIDAD DE CUIDADOS INTENSIVOS
}

\begin{abstract}
RESUMEN: El objetivo del estudio fue evaluar el cumplimiento de un paquete de prevención de neumonía asociada a ventilación mecánica en una unidad de cuidados intensivos. Se trata de un estudio descriptivo, transversal y cuantitativo realizado en un hospital público de Santa Catarina-Brasil. Los datos fueron recolectados en julio y agosto de 2012. La muestra correspondió a 1147 observaciones relacionadas con las cuatro prácticas que componen el paquete (cabecera elevada $30-45^{\circ}$; aspiración endotraqueal, la presión del manguito 20 a $30 \mathrm{~cm}$ de $\mathrm{H}_{2} \mathrm{O}$, la higiene oral con clorhexidina $0,12 \%$ ). Fue adoptado como un índice de cumplimiento la positividad esperada $>80 \%$. El análisis de datos reveló una tasa de cumplimiento general del paquete de 794 (69,2\%). Evaluadas separadamente, dos prácticas mostraron la conformidad esperada $(84,7 \%)$ : higiene oral y aspiración. La cabecera elevada fue la que se obtuvo el menor cumplimiento (55,5\%), seguida por la presión del manguito $(61,8 \%)$. Se observa la necesidad de estrategias que promuevan la calidad de la atención de todos los que componen del paquete para alcanzar la eficacia en su uso.
\end{abstract}

DESCRIPTORES: Unidades de cuidados intensivos. Neumonía asociada al ventilador. Evaluación en enfermería. Grupo de atención al paciente.

\section{INTRODUCTION}

The search for healthcare excellence and quality is a theme that has been acquiring increasingly more space in healthcare institutions and constitutes a part of professionals' daily routine. ${ }^{1-2}$ The concept of quality in healthcare is a topic of much discussion. In the classic literature, it is described as obtaining the greatest benefits at the lowest risks for the patient and at the lowest cost. ${ }^{3}$ In light of this definition, we can observe a fine line between healthcare quality and patient safety, the latter being defined as avoiding, preventing or improving adverse effects or injuries caused by healthcare processes. ${ }^{4}$

When considering patient care safety and quality in Intensive Care Units (ICU), it is essential to mention prevention of healthcare-associated infections (HAIs). Patients cared for in an ICU have five to ten times more chances of developing HAIs when compared to those from other hospital inpatient units, due to its clinical conditions and the variety of invasive procedures that are routinely conducted in treatment. ${ }^{5}$

Ventilator-associated pneumonia (VAP) is among one of the most prevalent HAIs and presents expressive morbimortality rates, potentially harming the health of individuals affected by this complication. ${ }^{6}$

In order to guarantee continuous improvement of patient care quality and safety, nurses must evaluate the outcomes of the care provided in order to (re)define care strategies. ${ }^{7}$ The implementation of bundles has proven to be successful for preventing VAP. This tool consists of a small and practical set of evidence-based practices that when performed collectively and reliably, result in the substantial improvement of healthcare outcomes. ${ }^{8}$
With this in mind, a group of nursing and physical therapy professionals of a general ICU in a public hospital of Santa Catarina, Brazil, elaborated a VAP prevention bundle, consisting of four elements: Head of bed elevation between $30-45^{\circ}$, endotracheal suctioning, cuff pressure between 20 $30 \mathrm{cmH}_{2} \mathrm{O}$, and oral care with $0.12 \%$ chlorhexidine. The care practices selected by these professionals were guided by evidence proving their effectiveness, as well as by the viability of their application in this specific ICU. ${ }^{9}$

However, establishing a bundle in and of itself is not enough to guarantee VAP prevention. We found it necessary to also monitor compliance with this set of practices in order to reach the effectiveness of its use in the ICU.

In this sense, we asked: how are professionals carrying out the care practices that compose the bundle to prevent ventilator-associated pneumonia in an Intensive Care Unit?

To answer this question, our goal was to evaluate compliance with the elements that compose the ventilator bundle in an Intensive Care Unit.

With this study, we intend to contribute to improving healthcare quality and VAP prevention in order to reduce the rates of this infection. The relevance of compliance with bundle use in unquestionable, for besides contributing to reduce morbidity and mortality among patients in intensive care, its repercussion can help reduce costs associated with treating these infections.

\section{METHOD}

This is a descriptive and cross-sectional study of quantitative nature conducted in the general ICU of a public hospital in Santa Catarina, 
which has 14 inpatient adult beds. Eighty-one nursing and physical therapy professionals work in this unit. Of these, 18 are nurses, 57 nursing technicians and six physical therapists. Nursing professionals are distributed in teams in morning, afternoon and night shifts, as established in resolution RDC7/2010 of the Brazilian Health Surveillance Agency. ${ }^{10}$ Physical therapists only work during day shifts.

Data were collected in June and August of 2012, for a 30-day period. Weekends were excluded due to the extra-long nature of day shifts, which could contribute towards a research bias. Practices selected for compliance observation/evaluation correspond to the four practices that compose the VAP prevention bundle for the ICU, context of our study: oral care with $0.12 \%$ chlorhexidine; head of bed elevation $\left(30-45^{\circ}\right)$; cuff pressure between 20 $30 \mathrm{cmH}_{2} \mathrm{O}$; and endotracheal suctioning criteria.

We selected a non-probability and convenience sample, corresponding to the opportunities for observation/evaluation of the four practices during the three work shifts. The data collection schedule was established as follows: in the morning, from 7:30 to 11; in the afternoon, from 2 to 5:30; and at night, from 7:30 to 11. Data were gathered by the researcher and two previously trained nurses with experience in intensive care.

The study was approved by the human research ethics committee of the Federal University of Santa Catarina (Protocol n. 1922/11), according to Resolution 196/96, established by the Brazilian National Health Council. ${ }^{11}$ We asked nursing and physical therapy professionals to sign a Term of Free and Informed Consent before practicing VAP prevention practices.

During practice observation, we used compliance criteria according to the evaluated procedure. For oral care, compliance consisted of conducting the technique with $0.12 \%$ chlorhexidine. Regarding head of bed elevation, we looked for an angle of $30-45^{\circ}$, except in cases when there was a clinical contraindication for this position. We attached an angle indicator at the head of all beds. Regarding cuff pressure, compliance was established as between 20-30 $\mathrm{cmH}_{2} \mathrm{O}$. For tracheal secretion suctioning, we took into account the application of the sterile technique, with the instillation of saline or any other type of solution. To characterize compliance, it also had to be conducted only when needed, such as in the presence of coughing with visible or audible secretion through pulmonary auscultation, increased work of breathing, pulse oximetry desaturation $<90 \%$, or after respiratory physical therapy.

In order to establish expected compliance of the evaluated practices, we used a Positivity Rate (PR) consisting of the following criteria: 100\% positivity when the item analyzed obtained a $100 \%$ compliance rate, which corresponded to desirable care; from 99 to $90 \%$, corresponding to adequate care; from 89 to $80 \%$, safe care; from 79 to $70 \%$, borderline care; and under $70 \%$, undesirable or sufferable care. ${ }^{12}$ According to this criteria, a PR $\geq 80 \%$ was defined as compliance in this study, which corresponded to safe care.

The data produced by the observations were charted and typed into an electronic Excel ${ }^{\circledR} 2007$ spreadsheet. Data were analyzed using descriptive statistics, with absolute and relative frequencies.

\section{RESULTS}

Throughout the period of our study, we conducted 1,147 (100\%) observations of VAP prevention practices that compose the bundles. Of this amount, $431(37.6 \%)$ corresponded to head of bed elevation; 321 (28\%), to suctioning of endotracheal; $225(19.6 \%)$, to verifying cuff; and $170(14.8 \%)$, to oral care. The greatest number of observation opportunities took place during the morning shift $(39.7 \%)$ and, the lowest, during the night shift $(24.7 \%)$, as displayed in table 1 .

Table 1 - Prevention practices for ventilator-associated pneumonia per work shift. Florianópolis, Santa Catarina, Brazil, 2013

\begin{tabular}{lccccccc}
\hline \multirow{2}{*}{ Observed practices } & \multicolumn{2}{c}{ Morning } & \multicolumn{2}{c}{ Afternoon } & \multicolumn{2}{c}{ Night } & \multicolumn{2}{c}{ Total } \\
& $\mathbf{n}$ & $\mathbf{0}$ & $\mathbf{n}$ & $\mathbf{\%}$ & $\mathbf{n}$ & $\mathbf{0}$ & $\mathbf{n}$ \\
\hline Head of bed elevation $30-45^{\circ}$ & 148 & 34.3 & 144 & 33.4 & 139 & 32.3 & 431 \\
Endotracheal suctioning & 126 & 39.2 & 131 & 40.8 & 64 & 20.0 & 321 \\
Cuff pressure 20-30 $\mathrm{cmH}_{2} \mathrm{O}$ & 115 & 51.1 & 79 & 35.1 & 31 & 13.8 & 225 \\
Oral care with chlorhexidine & 66 & 38.8 & 54 & 31.8 & 50 & 29.4 & 170 \\
\hline Total & $\mathbf{4 5 5}$ & $\mathbf{3 9 . 7}$ & $\mathbf{4 0 8}$ & $\mathbf{3 5 . 6}$ & $\mathbf{2 8 4}$ & $\mathbf{2 4 . 7}$ & $\mathbf{1 1 4 7}$ \\
\hline
\end{tabular}


Of the 1,147 observations conducted during the three work shifts, 794 (69.2\%) were in compliance. An overall analysis of each specific VAP prevention practice demonstrated that only two presented compliance $\geq 80 \%$, endotracheal suctioning and oral care, as illustrated in table 2.

Table 2 - Rates of compliance with ventilator-associated pneumonia prevention bundle. Florianópolis, Santa Catarina, Brazil, 2013

\begin{tabular}{lccccc}
\hline \multirow{2}{*}{ Observed practices } & \multicolumn{2}{c}{ Compliance } & \multicolumn{2}{c}{ Non-compliance } & Total \\
& $\mathbf{n}$ & $\mathbf{\%}$ & $\mathbf{n}$ & $\mathbf{0}$ & $\mathbf{n}$ \\
\hline Head of bed elevation $30-45^{\circ}$ & 239 & 55.5 & 192 & 44.5 & 431 \\
Endotracheal suctioning & 272 & 84.7 & 49 & 15.3 & 321 \\
Cuff pressure 20-30 $\mathrm{CmH}_{2} \mathrm{O}$ & 139 & 61.8 & 86 & 38.2 & 225 \\
Oral care with chlorhexidine & 144 & 84.7 & 26 & 15.3 & 170 \\
Total & $\mathbf{7 9 4}$ & $\mathbf{6 9 . 2}$ & $\mathbf{3 5 3}$ & $\mathbf{3 0 . 8}$ & $\mathbf{1 1 4 7}$ \\
\hline
\end{tabular}

The bundle analysis per work shift found that none of the shifts obtained expected compliance: $\geq 80 \%$. The morning shift obtained a rate closest to expected: $340(74.7 \%)$ of compliance, followed by the afternoon: $270(66.2 \%)$ and the night shift: 184 $(64.8 \%)$ of compliance, as shown in table 3 .

Table 3 - Compliance rate to ventilator-associated pneumonia prevention bundle per work shift. Florianópolis, Santa Catarina, Brazil, 2013

\begin{tabular}{lccccc}
\hline \multirow{2}{*}{ Shift/Care practice } & \multicolumn{2}{c}{ Compliance } & \multicolumn{2}{c}{ Non-compliance } & Total \\
& $\mathbf{n}$ & $\mathbf{0}$ & $\mathbf{n}$ & $\mathbf{\%}$ & $\mathbf{n}$ \\
\hline Morning & & & & & \\
Head of bed elevation 30-45 & 82 & 55.4 & 66 & 44.6 & 148 \\
Endotracheal suctioning & 116 & 92.0 & 10 & 8.0 & 126 \\
Cuff pressure 20-30 $\mathrm{cmH}_{2} \mathrm{O}$ & 85 & 74.0 & 30 & 26.0 & 115 \\
Oral care with chlorhexidine & 57 & 86.4 & 9 & 13.6 & 66 \\
\hline Subtotal & $\mathbf{3 4 0}$ & $\mathbf{7 4 . 7}$ & $\mathbf{1 1 5}$ & $\mathbf{2 5 . 3}$ & $\mathbf{4 5 5}$ \\
\hline Afternoon & & & & & \\
Head of bed elevation 30-45 & 82 & 56.9 & 62 & 43.1 & 144 \\
Endotracheal suctioning & 112 & 85.5 & 19 & 14.5 & 131 \\
Cuff pressure 20-30 cmHC $\mathrm{HC}_{2} \mathrm{O}$ & 33 & 41.8 & 46 & 58.2 & 79 \\
Oral care with chlorhexidine & 43 & 79.6 & 11 & 20.4 & 54 \\
\hline Subtotal & $\mathbf{2 7 0}$ & $\mathbf{6 6 . 2}$ & $\mathbf{1 3 8}$ & $\mathbf{3 3 . 8}$ & $\mathbf{4 0 8}$ \\
\hline Night & & & & & \\
Head of bed elevation $30-45^{\circ}$ & 75 & 54.0 & 64 & 46.0 & 139 \\
Endotracheal suctioning & 44 & 68.7 & 20 & 31.3 & 64 \\
Cuff pressure 20-30 $\mathrm{cmHC}_{2} \mathrm{O}$ & 21 & 67.8 & 10 & 32.2 & 31 \\
Oral care with chlorhexidine & 44 & 88.0 & 6 & 12.0 & 50 \\
\hline Subtotal & $\mathbf{1 8 4}$ & $\mathbf{6 4 . 8}$ & $\mathbf{1 0 0}$ & 35.2 & $\mathbf{2 8 4}$ \\
\hline Total & $\mathbf{7 9 4}$ & $\mathbf{6 9 . 2}$ & $\mathbf{3 5 3}$ & $\mathbf{3 0 . 8}$ & $\mathbf{1 1 4 7}$ \\
\hline
\end{tabular}

Head of bed elevation was the bundle practice that obtained the lowest rate of general compliance. This result was similar in each of the three work shifts, in which the head of bed was below the recommended angle $\left(30-45^{\circ}\right)$.

Endotracheal suctioning presented overall compliance $(\geq 80 \%)$, thus being considered a safe practice. When considering each work shift, this practice obtained expected quality during morn- ing and afternoon shifts, reaching compliance of $116(92 \%)$ and 112 (85.5\%), respectively. However, compliance with this practice during the night shift was only $44(68.7 \%)$.

Regarding cuff pressure, no shift obtained a safe compliance rate $(\geq 80 \%)$, being that the lowest rate was observed in the afternoon shift, $33(418 \%)$. The morning and night shift presented $85(74 \%)$ and $21(67.8 \%)$, respectively. 
Oral care obtained the highest compliance during the night shift, 44 (88\%); the morning shift reached $57(86.4 \%)$; however the afternoon shift presented a slightly lower percentage, $43(79.6 \%)$. Overall compliance with this practice reached 144 $(84.7 \%)$, which characterizes it as a safe practice.

\section{DISCUSSION}

This study recorded compliance with the four care practices that compose the VAP prevention bundle. Head of bed elevation between $30-45^{\circ}$ is a strongly recommended practice for preventing VAP, especially among patients who have been receiving enteral feeding. ${ }^{6,13}$ Despite considered a relatively simple measure and that does not incur in any additional costs, we found that the nursing and physical therapy team had low levels of adhesion (55.5\%) to this practice. Although all beds were equipped with an angle indicator, head of bed elevation did not obtain the expected conformity, being set at angles smaller than $30^{\circ}$, during the three work shifts, thus compromising the quality of care and exposing patients receiving invasive ventilation assistance to a greater risk for developing VAP due to bronchial suctioning.

A recent study conducted by nurses in a Brazilian ICU found similar results, in which head of bed elevation between $30-45^{\circ}$ presented a $46.26 \%$ to $52 \%$ compliance among different work shifts. ${ }^{14}$

Similarly, another Brazilian study displayed compliance below the expected rate $(\geq 80 \%)$, in which the head of bed elevation was maintained between $30-45^{\circ}$ in $72.1 \%$ of the observations. ${ }^{15}$

The literature provides some explanations for this difficulty in maintaining the head of bed elevated between $30-45^{\circ}$. According to the healthcare team, the patient "slides down" the bed, leading to risks for lesions among those with compromised skin integrity. They also mention the possibility of the patient feeling uncomfortable in this position. ${ }^{8}$

The suctioning of endotracheal secretions was another practice evaluated and presented $84.7 \%$ overall compliance, corresponding to safe care. However, this practice was not performed homogeneously throughout work shifts. The morning shift presented the highest compliance (92\%), followed by the afternoon shift $(85.5 \%)$, both considered adequate. However, the night shift presented a $68.7 \%$ compliance rate. The main reasons that lead to this rate being lower than expected during this shift was routine suctioning, such as before conducting the bed bath, or after oral care, with no consideration of the actual need for this procedure.

For many years, tracheal suctioning was conducted routinely every 1-2 hours, in order to remove secretions and prevent endotracheal tube occlusion. However, this practice is currently disencouraged. ${ }^{16-17}$ A systematic review indicates that routine suctioning considerably increases the risk of adverse events, such as hemodynamic alterations, oxygen desaturation and coughing up bloody mucus. Instead, it recommends that minimally invasive suctioning be preferred, only when necessary. ${ }^{18}$

Identifying the need for suctioning is a complex issue and requires knowledge and training of professionals inserted in clinical practice. Suctioning secretions is considered necessary when the patient presents cough, increased work of breathing, arterial desaturation and/or bradycardia, presence of audible or visible secretion, course breathing sounds during auscultation, or not enough lung volume after respiratory physical therapy to eliminate mobilized secretions. ${ }^{16-18}$

Verifying endotracheal cuff pressure is also a crucial practice for preventing VAP. The goal of this measure is to guarantee adequate seal of tracheal tube in order to prevent mirosuction of subglottic secretions and guarantee adequate ventilation. To this effect, cuff pressure must range from 20 to $30 \mathrm{cmH}_{2} \mathrm{O}^{6,13}$

The results of the present study indicate that this practice is being conducted at lower quality levels than expected, presenting a $61.8 \%$ overall compliance rate. The morning shift, with a $74 \%$ compliance rate, came the closest to expected, followed by the night shift, with $67.8 \%$. Compliance rate in the afternoon was $41.8 \%$, the lowest rate recorded separately with respect to all the evaluated practices. The determining factor leading to this result was that cuff pressure was maintained above the recommended levels during observation in all work shifts.

Among the complications caused by cuff hyperinflation, one of the greatest is the risk of decreased perfusion to the trachea, which can cause local ischemia, stenosis, subglottic scarring, and tracheal fistulas. ${ }^{19}$

One study conducted by physical therapists in an ICU in the south region of Brazil assessed the effectiveness of providing a nursing team with training for maintaining cuff pressure between 
20-30 $\mathrm{cmH}_{2} \mathrm{O}$. Before training, cuff pressure measurements were inadequate, above $30 \mathrm{cmH}_{2} \mathrm{O}$, and were $9.2 \% ; 11.9 \%$; and $13.7 \%$ during the morning, afternoon and night periods, respectively. After training, we found a $7.6 \% ; 4.1 \%$; and $5.2 \%$ rate of inadequate cuff pressure during the same periods. This reduction demonstrated that training was effective in making professionals aware of the harm of cuff hyperinflation and motivated them to maintain pressure levels within the range of recommended values. ${ }^{20}$

With respect to oral care with $0.12 \%$ chlorhexidine, our findings indicate adequate quality, with $84.7 \%$ of overall compliance. The night shift had the highest rate, $88 \%$, followed by the morning, $86.4 \%$. The afternoon shift had a compliance rate slightly below expected, $79.6 \%$.

A study developed by a nurse presented very similar results regarding adhesion to oral care with $0.12 \%$ chlorhexidine for patients receiving mechanical ventilation. Compliance was $90 \%$ in the morning shift, $73.7 \%$ at night and $72.9 \%$ in the afternoon. This study's expected compliance was also $80 \%$, which only occurred in the morning shift. ${ }^{21}$

In a study conducted in an ICU in France, researchers assessed how a multidisciplinary team adhered to eight VAP prevention measures, which consisted of head of bed elevation, suctioning of endotracheal secretions, cuff pressure and oral care. Compliance with practices was recorded before and after educational interventions. ${ }^{22}$ Results demonstrated that head of bed elevation compliance went from $5 \%$ to $58 \%$ after the interventions. Endotracheal secretion suctioning compliance went from $41 \%$ to $92 \%$. Cuff pressure was set to $>40 \%$ in the first assessments, but increased to an $89 \%$ compliance rate. Oral care with chlorhexidine, which initially had $47 \%$ compliance, reached $90 \%$ at the end of the study. ${ }^{22}$

We observed that, similarly to the results revealed in our study, the French study indicated head of bed elevation as the practice with lowest team adhesion, even after application of educational practices, followed by cuff pressure. However, suctioning of secretions and oral care had low compliance in the French study, becoming adequate only after the educational interventions.

\section{CONCLUSION}

Our findings reveal that bundle compliance was below expected. Regarding the assessment of the set of practices, the morning shift had the greatest compliance rate and the night shift, the lowest. However, none of the shifts obtained the expected rate $\geq 80 \%$. Such results demonstrate the frailty of care and how patients are exposed to developing VAP. Of the four recorded practices, only two presented the expected compliance. In order to reach quality care and safety for patients with mechanical ventilators through the use of the bundle, it is essential that all practices be in compliance.

As our expected compliance rate, we used a percentage established theoretically by researchers as safe, although in order to reach excellence of care, institutions must attempt $100 \%$ compliance. We believe that permanent and continuous educational practices are efficient tools for reaching effective VAP prevention practices. Quality of care reflects in the reduction of VAP cases and the consequential safety of patients receiving mechanical ventilation, and this requires multidisciplinary and concrete practices, as well as periodic audits.

\section{REFERENCES}

1. Vituri DW, Matsuda LM. Content validation of quality indicators for nursing care evaluation. Rev Esc Enferm USP. 2009 Jun; 43(2):429-37.

2. Claro CM, Krocockz DVC, Toffolleto MC, Padilha KG. Adverse events at the Intensive Care Unit: nurses' perception about the culture of no-punishment. Rev Esc Enferm USP. 2011 Mar; 45(1):167-72.

3. Donabedian A. The quality of medical care. Science. 1978 May; 200(4344):856-64.

4. Vicent C. Segurança do paciente: orientações para evitar eventos adversos. São Caetano do Sul (SP): Yendis, 2009.

5. Oliveira AC, Kovner CT, Silva RS. Nosocomial infection in an Intensive Care Unit in a Brazilian University Hospital. Rev Latino-Am Enferm. 2010 Mar-Apr; 8(2):233-9.

6. American Thoracic Society. Guidelines for the management of adults with hospital-acquired, ventilator-associated, and healthcare-associated pneumonia. Am J Respir Crit Care Med. 2005 Feb 15; 171(4):388-416.

7. Gabriel CS, Melo MRAC, Rocha FLR, Bernardes A, Miguelaci T, Silva MLP. Use of performance indicators in the nursing service of a public hospital. Rev Latino-Am Enfermagem. 2011 Sep-Out; 19(5):1247-54.

8. Institute for Healthcare Improvement. 5 million lives campaign: getting started kit: prevent ventilatorassociated pneumonia how-to guide. Cambridge (US): Institute for Healthcare Improvement; 2010. 
9. Silva SG, Nascimento ERP, Salles RK. Bundle to prevent ventilator-associated pneumonia: a collective construction. Texto Contexto Enferm. 2012 Out-Dez; 21(4):837-44.

10. Agência Nacional de Vigilância Sanitária (BR). Resolução da Diretoria Colegiada - RDC 7. Dispõe sobre os requisitos mínimos para funcionamento de Unidades de Terapia Intensiva e dá outras providências. Brasília (DF): Agência Nacional de Vigilância Sanitária; 2010.

11. Ministério da Saúde (BR). Conselho Nacional de Saúde, Resolução 196, de 10 de outubro de 1996: diretrizes e normas regulamentadoras de pesquisa envolvendo seres humanos. Brasília (DF); 1996.

12. Saupe R, Horr L. Auditoria em enfermagem. Rev Ciênc Saúde. 1982, 1(1):13-23.

13. Sociedade Brasileira de Pneumologia e Tisiologia. Diretrizes Brasileiras para o tratamento das pneumonias adquiridas no hospital e das pneumonias associadas à ventilação mecânica. J Bras Pneumol. 2007; 33(Supl1):S1-30.

14. Silva LTR, Laus AM, Canini SRMS, Hayashida M. Evaluation of prevention and control measures for ventilator-associated pneumonia. Rev Latino-Am Enferm. 2011 Nov-Dez; 19(6)1329-36.

15. Gonçalves FAF, Brasil VV, Ribeiro LCM, Tipple AFV. Nursing actions for the prevention of ventilator-associated pneumonia. Acta Paul Enferm. 2012; 25(esp1):101-7.

16. Pedersen CM, Rosendahl-Nielsen M, Hjermind J, Egerod I. Endotracheal suctioning of the adult intubated patient: what is the evidence? Intensive Crit Care Nurs. 2009 Feb; 25(1):21-30.

17. American Association of Respiratory Care - AARC. AARC clinical practice guideline: endotracheal suctioning of mechanically ventilated patients with artificial airways 2010. Respir Care. 2010 Jun; 55(6):758-64.

18. Favretto DO, Silveira RCCP, Canini SRMS, Garbin LM, Martins FTM, Dalri MCB. Endotracheal suction in intubated critically ill adult patients undergoing mechanical ventilation: a systematic review. Rev Latino-Am Enferm. 2012 Sep-Oct; 20(5):997-1007.

19. Sole ML, Su X, Talbert S, Penoyer DA, Kalita S, Jimenez E, et al. Evaluation of an intervention to maintain endotracheal tube cuff pressure within therapeutic range. Am J Crit Care. 2011 Mar; 20(2):109-17.

20. Penitenti RM, Vilches JIG, Oliveira JSC, Mizohata MGG, Correa DI, Alonso TRMB, et al. Cuff pressure control in intensive care unit: training effects. Rev Bras Ter Intensiva. 2010 Abr-Jun; 22(2):192-5.

21. Menezes IRSC. Avaliação da conformidade de práticas de controle e prevenção da pneumonia associada à ventilação mecânica em um hospital público de ensino [dissertação]. São Paulo (SP): Universidade de São Paulo, Escola de Enfermagem; 2009.

22. Bouadma L, Mourvillier B, Deiler V, Le CB, Lolom IBS, Regnier B, et al. A multifaceted program to prevent ventilator-associated pneumonia: Impact on compliance with preventive measures. Crit Care Med. 2010 Mar; 38(3):789-96. 